\title{
Human liver sulphamate sulphohydrolase
}

\section{Determinations of native protein and subunit $M_{\mathbf{r}}$ values and influence of substrate agylcone structure on catalytic properties}

\author{
Craig FREEMAN and John J. HOPWOOD \\ Department of Chemical Pathology, Adelaide Children's Hospital, King William Road, North Adelaide, S. Australia 5006, \\ Australia
}

\begin{abstract}
1. Human sulphamate sulphohydrolase was purified at least 20000 -fold to homogeneity from liver with a three-step four-column procedure, which consisted of a concanavalin A-Sepharose/Blue A agarose coupled step, and Bio-Gel HT step and then a CM-Sepharose step. The procedure was also used to purify enzyme from kidney and placenta. 2 . The subunit $M_{\mathrm{r}}$ of liver, kidney and placenta sulphamate sulphohydrolase was assessed to be 56000 by using SDS/polacrylamide-gel electrophoresis. The native protein $M_{\mathrm{r}}$ of enzyme from all three tissue sources was assessed by gel-permeation chromatography to be approx. 120000 on Sephacryl S-300 and 100000 on Fractogel TSK. It is probable that the native enzyme results from dimerization of subunits. 3. Kinetic parameters $\left(K_{\mathrm{m}}\right.$ and $\left.k_{\text {cat. }}\right)$ of human liver sulphamate sulphohydrolase were determined with a variety of substrates matching structural aspects of the physiological substrates in vivo, namely heparin and heparan sulphate. More structurally complex substrates, in which several aspects of the aglycone structure of the natural substrate were maintained, are turned over up to 372000 times faster than the monosaccharide substrate 2-sulphaminoglucosamine. Aglycone structures that influence substrate binding and/or enzyme activity were penultimate-residue C-6 carboxy and C-2 sulphate ester groups and a post-penultimate 2-sulphaminoglucosamine residue. The $\mathrm{C}-4$ hydroxy group of the 2-sulphaminoglucosamine under enzymic attack is involved in binding of substrate to enzyme. The presence of C-6 sulphate ester on the non-reducing end 2-sulphaminoglucosamine stimulates sulphamate bond hydrolysis and substrate affinity if the adjacent monosaccharide residue is idose or 2-sulphoidose, but strongly inhibits hydrolysis if the adjacent monosaccharide residue is iduronic acid. Sulphamate sulphohydrolase is an exoenzyme, since activity toward internal sulphamate bonds was not detected. 4 . The effect of incubation pH on enzyme activity towards the variety of substrates evaluated was complex and dependent on substrate aglycone structure. The presence of aglycone C-2 sulphate ester and aglycone C-6 carboxy groups and C-6 sulphate ester groups on the 2-sulphaminoglucosamine residue under attack considerably affect the $\mathrm{pH}$ response. Structurally complex substrates had two $\mathrm{pH}$ optima. Incubation temperature and buffer ionic strength markedly influenced $\mathrm{pH}$ optima and enzyme activity. $\mathrm{Cu}^{2+}$ and $\mathrm{SO}_{4}{ }^{2-}$ ions are potent inhibitors of enzyme activity.
\end{abstract}

\section{INTRODUCTION}

The lysosome requires the concerted action of up to eight exo-enzyme activities to achieve the degradation of heparin or heparan sulphate. We have previously reported the purification of one of these enzymes, sulphamate sulphohydrolase (EC 3.10.1.1), from human liver (Mahuran et al., 1983a). This enzyme is involved in the hydrolysis of the sulphamate bond in 2-sulphaminoglucosamine residues present in heparan sulphate and heparin. A deficiency in this lysosomal hydrolase is responsible for the pathogenesis of Sanfilippo A (mucopolysaccharidosis type IIIA) syndrome (Kresse, 1973; Matalon \& Dorfman, 1974). This is an autosomal recessive disorder of glycosaminoglycan catabolism leading to storage and excretion of excessive amounts of heparan sulphate and a variety of clinical phenotypes, but classically presenting with progressive mental retardation in conjunction with mild skeletal deformities (McKusick $\&$ Neufeld, 1983). In studies concerned with the development of a variety of oligosaccharide structures as diagnostic substrates, we reported a considerable effect of aglycone structure on expressed sulphamate sulphohydrolase activity in incubations containing homogenates of cultured skin fibroblasts, amniotic cells or leucocytes (Hopwood \& Elliott, 1981 a, b, $c, 1982$ ). The observations that substrates that possess as many of the structural features of the natural substrates, heparan

Abbreviations used: GlcA, D-glucuronic acid; GlcNS, 2-sulphoamino[1-3 $\mathrm{H}]$ glucosamine; GalNS, 2-sulphoamino[1-14 $\mathrm{C}]$ galactosamine; GlcN-Ido,

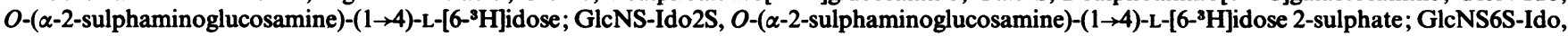

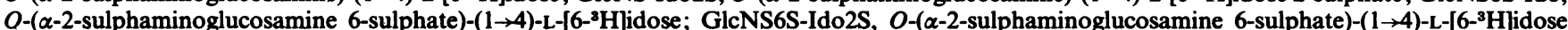

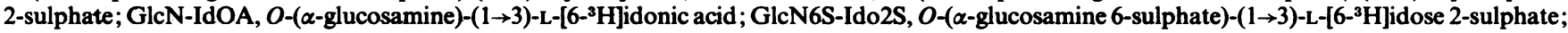

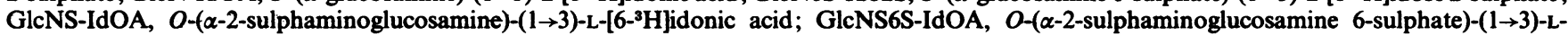

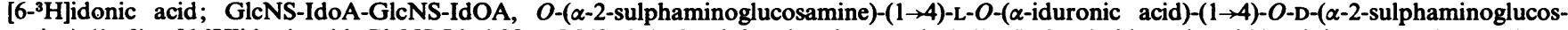

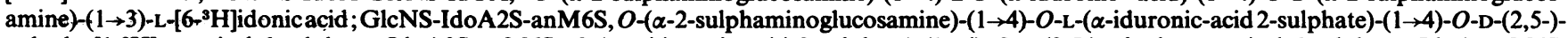
anhydro[1-3 $\mathrm{H}]$ mannitol 6-sulphate; IdoA2S-anM6S, $O$-( $\alpha$-L-iduronic acid 2-sulphate)-(1 $\rightarrow 4)-O$-D-(2,5-)anhydromannitol 6-sulphate; IdoA-anM6S,

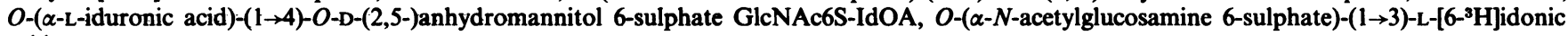
acid. 
sulphate and heparin, as possible generally result in the greatest rate of hydrolysis are re-examined in the present paper with the purified human liver enzyme.

\section{MATERIALS}

The radiolabelled oligosaccharides GlcNS-IdoA2SanM6S, GlcNS-IdoA-GlcNS-IdOA, GlcN-IdOA, GlcNSIdOA, GlcNS6S-Ido2S, GlcNS-Ido2S, GlcNS-Ido and GlcNS6S-Ido were prepared from heparin and generally had a specific radioactivity of $18 \mathrm{Ci} / \mathrm{mol}$ (Hopwood \& Elliott, 1981a,b,c, 1982), and the monosaccharide substrates GalNS and GlcNS were prepared from $\left[1-{ }^{-14} \mathrm{C}\right]$ GalN and $\left[1-{ }^{3} \mathrm{H}\right] \mathrm{GlcN}$ as previously described and had specific radioactivities of $52 \mathrm{Ci} / \mathrm{mol}$ and $30 \mathrm{Ci} / \mathrm{mmol}$ respectively (Hopwood \& Elliott 1981c). GlcNS6S-IdOA and GlcNAc6S-IdOA were prepared by 6-sulphation of GlcNS-IdoA and GlcNAc-IdoA before the reductive radiolabelling with $\mathrm{NaB}^{3} \mathrm{H}_{4}$ to a specific radioactivity of $18 \mathrm{Ci} / \mathrm{mol}$ (Hopwood \& Elliott, 1981c). The structures of the sulphamate sulphohydrolase substrates used in the present study are shown in Fig. 1. IdoA2S-anM6S and IdoA-anM6S were prepared by previously described methods (Hopwood, 1979).

Human liver and kidney were obtained from autopsies of normal individuals with intervals post mortem ranging from about $24 \mathrm{~h}$ to $72 \mathrm{~h}$, and placentas were obtained from normal deliveries, and all were kept frozen at $-20^{\circ} \mathrm{C}$ until needed. Pharmacia Fine Chemicals (Uppsala, Sweden) supplied CM-Sepharose CL-6B, concanavalin A-Sepharose, Sephacryl S-300 and the $M_{\mathrm{r}}$ standard kits for both gel-filtration and SDS/polyacrylamide-gel electrophoresis determinations of $\boldsymbol{M}_{\mathrm{r}}$. Amicon (Danvers, MA, U.S.A.) supplied Blue A Matrex agarose gel. Bio-Rad Laboratories (Richmond, CA, U.S.A.) supplied a silver stain kit and hydroxyapatite (Bio-Gel HT). Fractogel TSK HW-55(S) was purchased from Merck (Darmstadt, West Germany). Sigma Chemical Co. (St Louis, MO, U.S.A.) supplied bovine serum albumin (fraction V).

\section{METHODS}

\section{Sulphamate sulphohydrolase preparation}

Enzyme purification was as described previously (Mahuran et al., 1983a; Clements et al., 1983) except that the Green A agarose column was omitted and recycling of $\alpha$-methyl mannoside elution buffer was decreased to $48 \mathrm{~h}$. Enzyme activity eluted from the hydroxyapatite column was concentrated to $10 \mathrm{ml}$ and dialysed in an Amicon stirred cell (model 8200) with an Amicon Diaflo ultrafiltration membrane YM10 against $15 \mathrm{mM}-$ sodium dimethylglutarate buffer, $\mathrm{pH} \mathrm{6.0,} \mathrm{containing}$ $10 \mathrm{~mm}-\mathrm{NaCl}, 10 \%$ (v/v) glycerol and $0.1 \mathrm{~mm}$-dithiothreitol. The enzyme solution was applied to a $3 \mathrm{ml}$ CM-Sepharose column equilibrated in the same buffer and eluted with $5 \mathrm{ml}$ of $15 \mathrm{~mm}$-sodium dimethylglutarate buffer, $\mathrm{pH} 6.0$, containing $0.32 \mathrm{M}-\mathrm{NaCl}, 10 \%$ (v/v) glycerol and $0.1 \mathrm{~mm}$-dithiothreitol. The enzyme was stored in this buffer, and not subjected to gel filtration as previously described (Mahuran et al., 1983a). Provided that $\mathrm{NaCl}$ concentrations were maintained above $0.3 \mathrm{M}$, enzyme activity was stable in solutions stored at $4^{\circ}$ for more than a year.

Column eluates and pooled fractions were assayed for sulphamate sulphohydrolase activity as described previously (Mahuran et al., 1983a), with GlcNS-IdOA (440 pmol/assay) in medium containing bovine serum albumin $(9 \mu \mathrm{g} /$ assay) and $50 \mathrm{~mm}$-sodium acetate buffer, pH 5.6. During the latter stages of enzyme purification, particularly after the CM-Sepharose step, sulphamate sulphohydrolase activity appeared to be lower (up to 20 -fold) if bovine serum albumin was omitted from the standard assay mixture. This apparent loss of enzyme activity was not prevented by dialysis of enzyme preparations against $25 \mathrm{~mm}-\mathrm{NaCl}, 10$-fold concentration of enzyme protein or the addition of $30 \%(v / v)$ glycerol. Protein concentrations were determined on trichloroacetic acid/deoxycholate-precipitated samples (Mahuran et al., $1983 b$ ) by the method of Markwell et al. (1978).

\section{Subunit $\boldsymbol{M}_{\mathbf{r}}$}

SDS/polyacrylamide slab-gel electrophoresis was used to determine the $M_{\mathrm{r}}$ of polypeptide chains on reduced samples of protein precipitated by trichloroacetic acid, in a manner similar to that described before (Mahuran et al., 1983a). Gels were stained first with Coomassie Brilliant Blue R250, followed by silver staining (Merril et al., 1981).

\section{Native protein $\boldsymbol{M}_{\mathbf{r}}$}

Native protein $M_{\mathrm{r}}$ was determined by gel filtration on a $750 \mathrm{ml}$ Sephacryl S-300 column $(2.5 \mathrm{~cm} \times 155 \mathrm{~cm})$ or a $400 \mathrm{ml}$ Fractogel TSK HW-55(S) column $(2.5 \mathrm{~cm} \times 80 \mathrm{~cm})$ equilibrated in $15 \mathrm{~mm}$-sodium dimethylglutarate buffer, pH 5.0 or $\mathrm{pH} 6.0$, containing $0.5 \mathrm{M}-\mathrm{NaCl}, 10 \%$ (v/v) glycerol and $0.1 \mathrm{mM}$-dithiothreitol or in $10 \mathrm{~mm}$-Tris/HCl buffer, $\mathrm{pH} \mathrm{7.6,} \mathrm{containing} 0.3 \mathrm{M}$ $\mathrm{NaCl}, 10 \%$ (v/v) glycerol and 0.1 mM-dithiothreitol. The method of Andrews (1970) was used, with $K_{\mathrm{av}}$. plotted against $\log M_{\mathrm{r}}$ of the standard proteins, which were ferritin $\left(M_{\mathrm{r}} 440000\right)$, catalase $\left(M_{\mathrm{r}} 232000\right)$, fructose bisphosphate aldolase $\left(M_{\mathrm{r}} 158000\right)$, bovine serum albumin $\left(M_{\mathrm{r}} 67000\right)$ and ovalbumin $\left(M_{\mathrm{r}} 43000\right)$.

\section{Kinetic experiments}

Enzyme solutions used in these kinetic experiments were dialysed with $300 \mu \mathrm{g}$ of bovine serum albumin $/ \mathrm{ml}$ against buffer containing 5 mM-sodium acetate, $\mathrm{pH} 5.0$, $30 \%$ (v/v) glycerol, $25 \mathrm{~mm}-\mathrm{NaCl}$ and $0.1 \mathrm{~mm}$-dithiothreitol for $16 \mathrm{~h}$ at $4^{\circ} \mathrm{C}$. These enzyme preparations maintained constant activity for at least 3 months at $4{ }^{\circ} \mathrm{C}$. Enzyme preparations dialysed in the absence of bovine serum albumin against the above buffer mixture retained $65 \%$ of their initial activity if assayed in the presence of $300 \mu \mathrm{g}$ of bovine serum albumin $/ \mathrm{ml}$. However, storage of the albumin-free enzyme preparation at $4{ }^{\circ} \mathrm{C}$ resulted in a $65 \%$ decrease in activity during $24 \mathrm{~h}$.

pH-enzyme activity profiles were obtained by using a standard $20 \mu \mathrm{l}$ assay mixture containing $5 \mu \mathrm{l}$ of $0.1 \mathrm{M}$ sodium acetate buffer, $0.1 \mathrm{M}$-sodium formate buffer or $0.1 \mathrm{M}$-Tris/acetate buffer ( $\mathrm{pH}$ indicated), $1 \mu \mathrm{l}$ of substrate in aqueous solution and $13 \mu \mathrm{l}$ of any additive or water. Reactions were initiated by the addition of $1 \mu \mathrm{l}$ of dialysed enzyme solution (equivalent to approx. $20 \mathrm{ng}$ of sulphamate sulphohydrolase protein and $300 \mathrm{ng}$ of bovine serum albumin). Incubation times and temperatures were optimized to give a percentage breakdown of substrate in the range $5-25 \%$, which was linear with respect to time at both $37^{\circ} \mathrm{C}$ and $60^{\circ} \mathrm{C}$. Incubation temperatures of $60^{\circ} \mathrm{C}$ were used to produce measurable 
amounts of product from those poorly hydrolysed substrates such as GlcNS and GalNS. This increased activity probably results from thermal activation of the enzyme (Hopwood \& Elliott, 1981b). Although the conversion into product was considerably lower in the absence of bovine serum albumin, it was linear with respect to enzyme protein and time at both temperatures. Buffered $\mathrm{pH}$ values of incubation mixtures were measured values at indicated incubation temperatures. Reactions were terminated by the addition of $1 \mu \mathrm{l}$ of $0.2 \mathrm{M}-\mathrm{Na}_{2} \mathrm{SO}_{4}$ and the reaction vials plunged into a solid- $\mathrm{CO}_{2}$ /ethanol bath.

The substrate was separated from the product by high-voltage electrophoresis on Whatman $3 \mathrm{MM}$ chromatography paper in $1.74 \mathrm{M}$-formic acid, $\mathrm{pH} 1.7$, at $45 \mathrm{~V} / \mathrm{cm}$ for $40 \mathrm{~min}$ in a Shandon Southern model L-24 system (Shandon Southern Products, Runcorn, Cheshire, U.K.). The strips were scanned for radioactivity on a Packard model 7201 radiochromatogram scanner (Packard, Chicago, IL, U.S.A.). Areas of radioactivity were cut from the strip, placed in a $20 \mathrm{ml}$ glass scintillation vial along with $4 \mathrm{ml}$ of water and $10 \mathrm{ml}$ of PCS solubilizer (Amersham/Searle, Arlington Heights, IL, U.S.A.) and their radioactivities counted in a Searle model 6868 ISOCAP/300 ambient-temperature liquid-scintillation counter (Searle Analytic, Des Plaines, IL, U.S.A.). Enzyme activity was determined from the percentage breakdown of each substrate to product.

Concentrations of each substrate, temperature and incubation time for the generation of $\mathrm{pH}$-activity profiles were: GlcNS-IdOA $\left(22 \mu \mathrm{M}, 37^{\circ} \mathrm{C}\right.$ and $1 \mathrm{~h} ; 22 \mu \mathrm{M}, 60^{\circ} \mathrm{C}$ and $0.2 \mathrm{~h})$, GlcNS-IdoA-GlcNS-IdOA $\left(36.5 \mu \mathrm{M}, 37^{\circ} \mathrm{C}\right.$ and $0.1 \mathrm{~h})$, GlcNS-IdoA2S-anM6S $\left(43 \mu \mathrm{M}, 37^{\circ} \mathrm{C}\right.$ and $0.16 \mathrm{~h})$, GlcNS6S-Ido $2 \mathrm{~S}\left(25 \mu \mathrm{M}, 37^{\circ} \mathrm{C}\right.$ and $\left.2.5 \mathrm{~h}\right)$, GlcNS $\left(1 \mu \mathrm{M}, 60^{\circ} \mathrm{C}\right.$ and $\left.12 \mathrm{~h}\right)$, GalNS $\left(5 \mu \mathrm{M}, 60^{\circ} \mathrm{C}\right.$ and $\left.16 \mathrm{~h}\right)$, GlcNS-Ido $\left(17.5 \mu \mathrm{M}, 37^{\circ} \mathrm{C}\right.$ and $16 \mathrm{~h}$ ), GlcNS6S-IdOA $\left(29 \mu \mathrm{M}, 37^{\circ} \mathrm{C}\right.$ and $\left.16 \mathrm{~h}\right)$, GlcNS6S-Ido $\left(20 \mu \mathrm{M}, 37^{\circ} \mathrm{C}\right.$ and $16 \mathrm{~h})$ and GlcNS-Ido2S $\left(12 \mu \mathrm{M}, 37^{\circ} \mathrm{C}\right.$ and $\left.5 \mathrm{~h}\right)$.

Kinetic data $\left(k_{\text {cat. }}, K_{\mathrm{m}}\right)$ were obtained with assay conditions similar to those for the $\mathrm{pH}$-activity profile. Substrate concentration ranged from 1 to $100 \mu \mathrm{M}$ (50-750 nM for GlcNS). Incubation time was adjusted to be within the linear range for substrate hydrolysis. Incubations were performed at the optimal $\mathrm{pH}$ for each substrate.

\section{RESULTS}

\section{Purification of sulphamate sulphohydrolase}

Since we first reported the isolation and purification of sulphamate sulphohydrolase from human liver (Mahuran et al., 1983a) we have performed more than 50 preparations from liver by the modified and faster method described above. The yield varied from $9 \%$ to $21 \%$ of the total activity present in the liver homogenate. We have also purified human kidney and placenta sulphamate sulphohydrolase to homogeneity. Compared with liver, kidney was a rich source of the enzyme, giving 10-20 times more enzyme activity per wet wt. of tissue, whereas placenta gave about one-tenth of that present in liver.

Molecular-sieve chromatography of sulphamate sulphohydrolase on either Sephacryl S-300 or Fractogel TSK revealed a single peak of activity, corresponding to an $M_{\mathrm{r}}$ of 122000 or 100000 respectively. A total of six different enzyme preparations applied to the same Sephacryl S-300 column were eluted as a single peak of activity within the $M_{\mathrm{r}}$ range 120000-125000. Sulphamate sulphohydrolases isolated, by the above method, from human kidney and placenta were eluted from Sephacryl S-300 as single peaks corresponding to $M_{\mathrm{r}} 125000$ and 123000 respectively

We had previously reported that enzymically active sulphamate sulphohydrolase from human liver was eluted with $0.3 \mathrm{M}-\mathrm{NaCl}$ in $10 \mathrm{~mm}-\mathrm{Tris} / \mathrm{HCl}$ buffer, pH 7.6, from Sephacryl S-300 with an apparent $M_{\mathrm{r}}$ of 190000 and inactive enzyme protein with an $M_{\mathrm{r}}$ of 350000 (Mahuran et al., 1983a). These results were explained by suggesting that the enzymically active sulphamate sulphohydrolase was a result of aggregation of a subunit and that further aggregation produced an inactive enzyme complex. The effect of buffer composition on apparent $M_{\mathrm{r}}$ of sulphamate sulphohydrolase by gel filtration on Fractogel TSK was evaluated by using three different buffers $(0.5 \mathrm{M}-\mathrm{NaCl}$ in $0.1 \mathrm{M}$-dimethylglutarate buffer, $\mathrm{pH} 6.0,0.5 \mathrm{M}-\mathrm{NaCl}$ in $0.1 \mathrm{M}$-dimethylglutarate buffer, $\mathrm{pH} 5.0$, and $0.3 \mathrm{M}-\mathrm{NaCl}$ in $10 \mathrm{~mm}$-Tris $/ \mathrm{HCl}$ buffer, $\mathrm{pH}$ 7.6). Sulphamate sulphohydrolase was eluted by each buffer as a single peak of activity corresponding to an $M_{\mathrm{r}}$ between 90000 and 110000 .

Substrate GlcNS-IdoA2S-anM6S was used to assay Sephacryl S-300 column fractions for sulphamate sulphohydrolase activity at this substrate's two optimum incubation $\mathrm{pH}$ values of 3.6 and 5.6. The single-peak profiles of enzyme activity were identical with that obtained with substrate GlcNS-IdOA at an incubation $\mathrm{pH}$ of 5.6. GlcNS-IdoA2S-anM6S was also used to assess enzyme activity in fractions eluted from the Blue A Matrex agarose column in the purification scheme. The profiles of activity obtained under incubation conditions of $\mathrm{pH} 3.6$ and $\mathrm{pH} 5.6$ were identical with that obtained with substrate GlcNS-IdOA at $\mathrm{pH}$ 5.6. Isoelectric focusing of the concanavalin A-Sepharose elute as previously described (Mahuran et al., 1983a) produced a single peak of sulphamate sulphohydrolase activity assessed with substrate GlcNS-IdOA at an incubation $\mathrm{pH}$ of 5.6 or with GlcNS-IdoA2S-anM6S at an incubation $\mathrm{pH}$ of 3.6 or of 5.6. The pI of the single peak of enzyme activity was 6.8 .

Assessment of the subunit $M_{\mathrm{r}}$ of sulphamate sulphohydrolase by SDS/polyacrylamide-gel electrophoresis of fractions from the CM-Sepharose step revealed a single band of $M_{r} 56000$ for all liver preparations. Enzyme not subjected to reduction with dithioerythritol before SDS/polyacrylamide-gel electrophoresis also had an $M_{\mathrm{r}}$ of 56000 . Human kidney and placenta sulphamate sulphohydrolases gave on SDS/polyacrylamide-gel electrophoresis subunit $M_{\mathrm{r}}$ values identical with that of the liver enzyme.

\section{Effect of pH on sulphamate sulphohydrolase activity}

The $\mathrm{pH}$ optimum of sulphamate sulphohydrolase was tested with each substrate (Fig. 1), and is shown to be dependent on substrate structure and for some substrates to be complex (Fig. 2). The pH-activity profiles for GlcNS-IdOA, GlcNS6S-Ido2S and GlcNS-IdoA-GlcNSIdOA assessed in the absence of bovine serum albumin, although having much lower enzyme activities, were equivalent to profiles (Fig. 2) obtained in the presence of albumin. The mechanism by which albumin stimulates enzyme activity is unknown. 
等
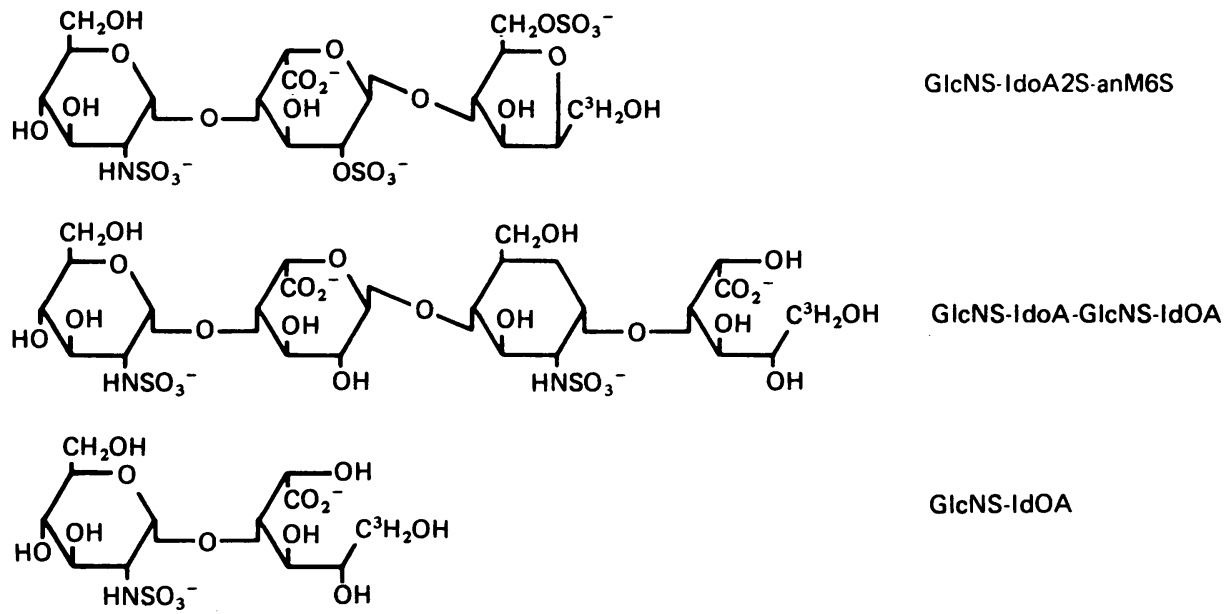

GIcNS-IdOA

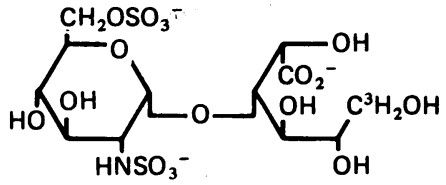

GIcNS6S-IdOA

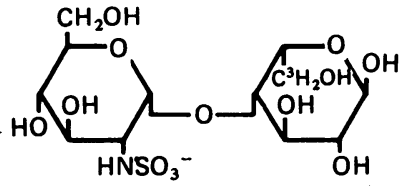

GIcNS-Ido

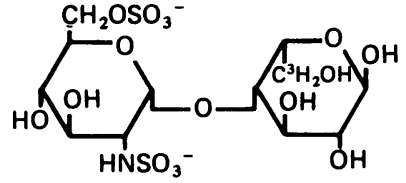
GIcNS6S-Ido

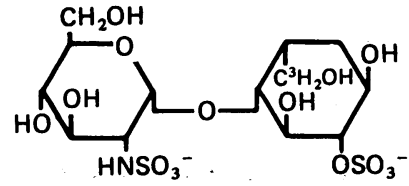
GIcNS-Ido2S

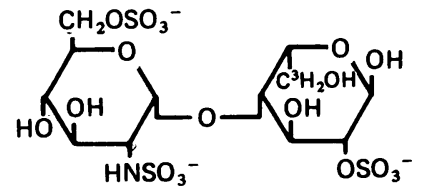<smiles>O=[N+]([O-])[C@@H]1[C@H]2O[C@@H](O2)[C@@H](CO)O[C@@H]1O</smiles>

GICNS<smiles>O=[N+]([O-])[C@H]1[C@@H](O)O[C@H](CO)[C@H](O)[C@H]1O</smiles>

GalNS

Fig. 1. Structures of substrates of sulphamate sulphohydrolase used in this study, together with the structure of the natural substrate from which they were derived 

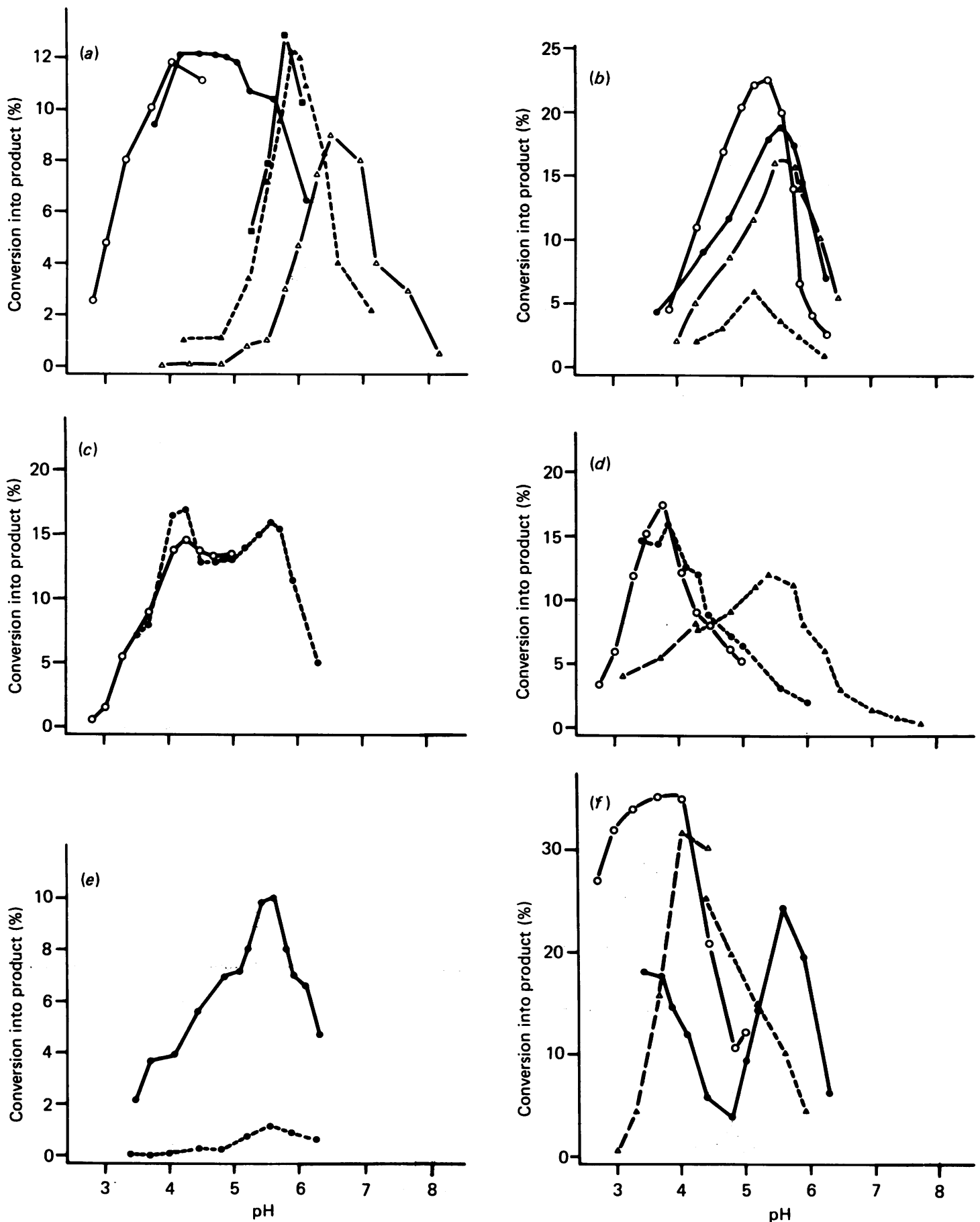

Fig. 2. Hydrolysis by liver sulphamate sulphohydrolase of a variety of substrates as a function of incubation pH

(a) GlcNS-Ido in sodium acetate $(\square-\square)$ and Tris/acetate $(\Delta---\Delta)$ at $60^{\circ} \mathrm{C}$ and Tris/acetate $(\triangle-\triangle)$ at $37^{\circ} \mathrm{C}$; GlcNS6S-Ido in sodium formate $(\mathrm{O}-\mathrm{O})$ and sodium acetate $(\mathrm{O}-\mathrm{O})$ at $37^{\circ} \mathrm{C}$. (b) GlcNS-IdOA in sodium acetate $\left(\mathrm{O}^{\circ}-\mathrm{O}^{\circ}\right.$ at $37^{\circ} \mathrm{C}$, Tris/acetate $(\Delta-\Delta)$ at $37^{\circ} \mathrm{C}$, sodium acetate $(\mathrm{O}-\mathrm{O})$ at $60^{\circ} \mathrm{C}$ and sodium acetate plus $0.1 \mathrm{M}-\mathrm{NaCl}(\mathbf{\Lambda}---\Delta)$ at $37^{\circ} \mathrm{C}$. $(c)$ GlcNS6S-IdOA in sodium formate $(\mathrm{O}-\mathrm{O})$ and sodium acetate $\left(\mathrm{O}_{---}\right)$at $37^{\circ} \mathrm{C}$. $(d)$ GlcNS-Ido2S in sodium formate $(\boldsymbol{\Delta}--\boldsymbol{\Delta})$ and Tris/acetate $(\triangle---\Delta)$ at $37^{\circ} \mathrm{C}$; GlcNS6S-Ido2S in sodium formate $(\mathrm{O}-\mathrm{O})$ and sodium acetate $\left(\mathrm{O}^{----O)}\right.$ at $37^{\circ} \mathrm{C}$. $(e)$ GlcNS in sodium acetate $\left(0_{----)}\right)$at $60^{\circ} \mathrm{C}$; GlcNS-IdoA-GlcNS-IdOA in sodium acetate $\left(0_{-}\right)$at $37^{\circ} \mathrm{C}$. $(f) \mathrm{GlcNS}$ IdoA2S-anM6S in sodium formate $\left(\mathrm{O}_{-} \mathrm{O}\right)$, sodium acetate $\left(\mathrm{O}_{-}-\right)^{-}$, sodium formate plus $0.1 \mathrm{M}-\mathrm{NaCl}(\boldsymbol{\Delta}--\mathbf{\Delta})$ and sodium acetate plus $0.1 \mathrm{M}-\mathrm{NaCl}(\mathbf{\Delta - - - \Delta )})$ at $37^{\circ} \mathrm{C}$.

In general the presence of C-6 sulphate ester on the GlcNS residue of the disaccharide substrates GlcNSIdOA, GlcNS-Ido2S and GlcNS-Ido to produce substrates GlcNS6S-IdOA, GlcNS6S-Ido2S and GlcNS6S-Ido res- pectively shifted the $\mathrm{pH}$ optimum from the range 5.5-6.7 down to 3.8-4.2. Substrate GlcNS6S-IdOA exhibited a profile with distinct peaks of enzyme activity at $\mathrm{pH} 4.2$ and 5.6. It was also noticeable.(Fig. $2 f$ ) that sulphamate 
Table 1. Human liver sulphamate sulphohydrolase activity towards a variety of substrates

\begin{tabular}{lccccr}
\hline \multicolumn{1}{c}{ Substrate } & $\mathrm{pH}$ & $K_{\mathrm{m}}(\mu \mathrm{M})$ & $\begin{array}{c}k_{\text {cat. }} \\
\text { (turnover number) } \\
\text { of enzyme) }\end{array}$ & $\begin{array}{c}k_{\text {cat. }} / K_{\mathrm{m}} \\
\text { (catalytic } \\
\text { efficiency) }\end{array}$ & $\begin{array}{r}\text { Relative } \\
\text { catalytic } \\
\text { efficiency* }\end{array}$ \\
\hline GlcNS & $5.6 \dagger$ & $0.7 \dagger$ & $0.0021 \dagger$ & $3 \dagger$ & 1.00 \\
GalNS & $5.6 \dagger$ & $16.1 \dagger$ & $(0.0005)$ & $0.73)$ & 0.06 \\
GlcNS-Ido & & & $0.0029 \dagger$ & $(0.04)$ & 7.40 \\
GlcNS-Ido2S & 6.7 & 7.7 & $0.0007)$ & 5.4 & 36 \\
GlcNS-IdOA & 5.5 & 4.1 & 0.11 & 26.5 & 1477 \\
GlcNS-IdOA & 5.6 & 35.0 & 9.19 & 5057 & 6927 \\
GlcNS-IdoA-GlcNS-IdOA & $5.4 \dagger$ & $40.8 \dagger$ & $44 \dagger$ & 49051 & 67193 \\
GlcNS-IdoA2S-anM6S & 5.6 & 10.3 & 52 & 22073 & 30237 \\
GlcNS6S-Ido & 3.6 & 3.8 & 186 & 20.2 & 28 \\
GlcNS6S-Ido2S & 5.6 & 5.3 & 117 & 283 & 388 \\
GlcNS6S-IdOA & 4.2 & 3.0 & 0.061 & 36.7 & 53
\end{tabular}

* $k_{\text {cat. }} / K_{\mathrm{m}}$ calculated relative to a value for GlcNS $=1$ at $37^{\circ} \mathrm{C}$.

$\dagger$ Incubation temperature $60^{\circ} \mathrm{C}$, whereas all other incubations at $37^{\circ} \mathrm{C}$; numbers in parentheses represent the calculated values for incubation at $37^{\circ} \mathrm{C}$ obtained by using a factor generated from GlcNS-IdOA incubated at $37^{\circ} \mathrm{C}$ and $60^{\circ} \mathrm{C}$ (Hopwood \& Elliott, 1981b).

sulphohydrolase activity assessed with GlcNS-IdoA2SanM6S had distinct $\mathrm{pH}$ maxima at 3.8 and 5.6.

The addition of idose to GlcNS, to produce substrate GlcNS-Ido, increased the enzyme pH optimum from 5.6 to 6.7. The presence of a C-2 sulphate ester or a C-6 carboxy group on the idose residue of GlcNS-Ido, to produce substrates GlcNS-Ido2S and GlcNS-IdOA respectively, lowered the sulphamate sulphohydrolase $\mathrm{pH}$ optimum to 5.5. GlcNS-Ido2S has a broad $\mathrm{pH}$

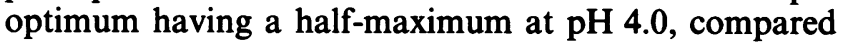
with no detectable activity towards GlcNS-Ido at this $\mathrm{pH}$. The tetrasaccharide substrate GlcNS-IdoA-GlcNSIdOA, containing both an internal GlcNS and a nonreducing end GlcNS residue, was de- $N$-sulphated with a pH optimum of 5.5.

The effect of temperature on the $\mathrm{pH}$ optima was considerable. At $37^{\circ} \mathrm{C}$ substrates GlcNS-IdOA and GlcNS-Ido exhibit pH optima of 5.6 and 6.7 respectively, whereas at $60^{\circ} \mathrm{C}$ these two substrates had $\mathrm{pH}$ optima of 5.4 and 5.8 respectively. These results suggest that the $\mathrm{pH}$ optimum of 5.6 for substrates GalNS and GlcNS at $60^{\circ} \mathrm{C}$ is probably higher at an incubation temperature of $37^{\circ} \mathrm{C}$.

\section{Kinetic properties of purified sulphamate sulphohydrolase}

$K_{\mathrm{m}}$ and $V$ values were obtained from Lineweaver-Burk plots. Comparison of the binding and catalysis of various substrates (Fig. 1) can be made from the data shown in Table 1. Incubation at $60^{\circ} \mathrm{C}$ for substrates GalNS and GlcNS was necessary for detection of de- $N$-sulphation of those substrates. Whereas GalNS and GlcNS have similar turnover numbers, the $K_{\mathrm{m}}$ value of GlcNS was 23 times lower than that of GalNS. The addition of idose to GlcNS to give the disaccharide substrate GlcNS-Ido resulted in a 10-fold increase in $K_{\mathrm{m}}$ and an 80-fold higher $k_{\text {cat. }}$ value. The addition of $\mathrm{C}-2$ sulphate ester or C-6 carboxy group to the idose residue in GlcNS-Ido to give GlcNS-Ido2S or GlcNS-IdOA respectively resulted in a 5-fold or 50-fold increase in ability of the disaccharide to undergo de- $N$-sulphation. Incubation of GlcNS-IdOA at $37^{\circ} \mathrm{C}$ and $60^{\circ} \mathrm{C}$ gave similar $K_{m}$ values but a 4.8 -fold higher turnover number at the higher temperature. The $K_{\mathrm{m}}$ values for GlcNS-Ido2S and GlcNS-IdOA were significantly different from that of GlcNS-Ido, being 2-fold lower and 5-fold higher respectively. Extension of the disaccharide GlcNS-IdOA to the tetrasaccharide GlcNS-IdoA-GlcNS-IdOA led to a 4-fold decrease in $K_{\mathrm{m}}$ and a 20 -fold increase in catalytic efficiency. The more complex substrate GlcNS-IdoA2S-anM6S, with a IdoA2S aglycone residue, was by far the most sensitive substrate in that its catalytic efficiency was up to 67000 -fold and 1100000-fold higher than the values observed for GlcNS and GalNS respectively. At an incubation $\mathrm{pH}$ of 5.6 substrate GlcNS-IdoA2S-anM6S has a $K_{\mathrm{m}}$ value 2 -fold and 6-fold lower than those observed for GlcNS-IdoA-GlcNS-IdOA and GlcNSIdOA. Under the conditions used the catalytic efficiency of the enzyme toward GlcNS-IdoA2S-anM6S at pH 3.6 was approximately twice that observed at $\mathrm{pH} 5.6$.

The effect on $K_{\mathrm{m}}$ and catalytic efficiency of a sulphate ester at the C-6 position of the non-reducing end GlcNS residue of substrates GlcNS-Ido, GlcNS-Ido2S and GlcNS-IdOA, shown in Table 1, is complex. First, the addition of C-6 sulphate to GlcNS-Ido (to produce GlcNS6S-Ido) decreased the $K_{\mathrm{m}}$ value by 2 -fold and increased catalytic efficiency by 4-fold. Secondly, the addition of sulphate ester to the C-6 hydroxy group of substrate GlcNS-Ido2S (to yield GlcNS6S-Ido2S) resulted in no change in $K_{\mathrm{m}}$ and a 30 -fold increase in $k_{\text {cat. }}$ value. Thirdly, the addition of sulphate to GlcNS-IdOA to produce GlcNS6S-IdOA resulted in a 15-fold decrease in $K_{\mathrm{m}}$ value and a 100 -fold decrease in $k_{\text {cat. }}$ value at an incubation $\mathrm{pH}$ of 5.6 .

Incubation of GlcNS-IdoA-GlcNS-IdOA under conditions $\left(60^{\circ} \mathrm{C}\right.$ for $16 \mathrm{~h}$ at $\mathrm{pH}$ 5.6) that would be expected 
to cause complete de- $N$-sulphation 100 times over failed to produce detectable amounts of completely de- $N$ sulphated tetrasaccharide GlcN-IdoA-GlcN-IdOA.

Effect of salts and substrate analogues on sulphamate sulphohydrolase

In a study similar to that carried out with leucocyte and fibroblast extracts (Hopwood \& Elliott, 1981a, b, c) we examined the effect of increasing $\mathrm{NaCl}$ and $\mathrm{Na}_{2} \mathrm{SO}_{4}$ concentration on the enzyme activity towards substrate GlcNS-IdoA2S-anM6S, GlcNS-IdoA-GlcNS-IdOA and GlcNS-IdOA during incubation at pH 5.6. Enzyme activity towards GlcNS-IdoA-GlcNS-IdOA was inhibited with $\mathrm{NaCl}$, whereas sulphamate sulphohydrolase activity towards both GlcNS-IdoA2S-anM6S and GlcNSIdOA was slightly stimulated on the addition of $\mathrm{NaCl}$ to $20 \mathrm{~mm}$, but then inhibited at $\mathrm{NaCl}$ concentrations above $50 \mathrm{~mm}$ (Fig. 3). $\mathrm{NaCl}$ inhibition of sulphamate sulphohydrolase activity with GlcNS-IdoA-GlcNS-IdOA was considerably greater than that observed with GlcNSIdoA2S-anM6S or GlcNS-IdOA. Similar profiles for the effect of $\mathrm{NaCl}$ concentration on enzyme activity were observed towards GlcNS-IdoA2S-anM6S when incubation was at $\mathrm{pH} 3.8$ or 5.6. The addition of $\mathrm{Na}_{2} \mathrm{SO}_{4}$ resulted in the potent inhibition of enzyme activity towards GlcNS-IdoA2S-anM6S, GlcNS-IdoA-GlcNSIdOA and GlcNS-IdOA at an incubation pH of 5.6 (Fig. 3).

The addition of $0.1 \mathrm{M}-\mathrm{NaCl}$ was observed to have a marked effect on the $\mathrm{pH}$-activity profile with the two substrates GlcNS-IdoA2S-anM6S and GlcNS-IdOA. Fig. $2(f)$ shows that the distinct $\mathrm{pH}$ optima present at 3.8 and 5.6 with GlcNS-IdoA2S-anM6S in the absence of $\mathrm{NaCl}$ are removed in incubations containing $0.1 \mathrm{M}-\mathrm{NaCl}$. In $0.1 \mathrm{M}-\mathrm{NaCl}$ the $\mathrm{pH}$ optimum of the enzyme activity towards GlcNS-IdoA2S-anM6S was 4.0-4.5. These results suggest that $0.1 \mathrm{M}-\mathrm{NaCl}$ inhibits enzyme activity below $\mathrm{pH} 3.8$ and above $\mathrm{pH} 5.0$, but stimulates the enzyme activity towards GlcNS-IdoA2S-anM6S between $\mathrm{pH} 4.0$ and 5.0. $\mathrm{NaCl}$ at a concentration of $0.1 \mathrm{M}$ inhibits sulphamate sulphohydrolase activity towards GlcNSIdOA at all $\mathrm{pH}$ values tested, and shifted the $\mathrm{pH}$ optimum from 5.6 to 5.2 (Fig. $2 b$ ).

Under standard incubation conditions with GlcNSIdOA no requirement for or inhibition of enzyme activity by $10 \mathrm{mM}-\mathrm{CaCl}_{2},-\mathrm{MgCl}_{2},-\mathrm{MnCl}_{2},-\mathrm{KCl}$ or $-\mathrm{LiCl}$ could be shown. $\mathrm{CuCl}_{2}$ at concentrations of $10,1,0.1$ and $0.01 \mathrm{mM}$ decreased enzyme activities to $0,12,23$ and $51 \%$ respectively of the control value. Addition of GlcN-IdOA at concentrations of 173,17 or $1.7 \mu \mathrm{M}$ to standard incubations containing GleNS-IdOA $(22 \mu \mathrm{M})$ resulted in the inhibition of enzyme activity by 86,37 and $4 \%$ respectively of control enzyme activity. GlcN at concentrations of 1.0 and $0.1 \mathrm{mM}$ and GlcA at concentrations up to $2 \mathrm{mM}$ added to standard incubations of GlcNS-IdOA did not inhibit enzyme activity. GlcNAc6S-IdOA, IdoA2S-anM6S and IdoA-anM6S at concentrations of $200 \mu \mathrm{M}$ inhibited enzyme activity towards GlcNS-IdOA by $40 \%, 62 \%$ and $55 \%$ respectively. Sulphamate sulphohydrolase preparations were free of enzyme activity ( $N$-acetylglucosamine 6-sulphate sulphatase, iduronate 2-sulphate sulphatase and $\alpha$-Liduronidase respectively) towards GlcNAc6S-IdOA, IdoA2S-anM6S and IdoA-anM6S when these substrates were incubated for up to $16 \mathrm{~h}$ under optimum conditions (Hopwood, 1979; Hopwood \& Elliott, 1982).
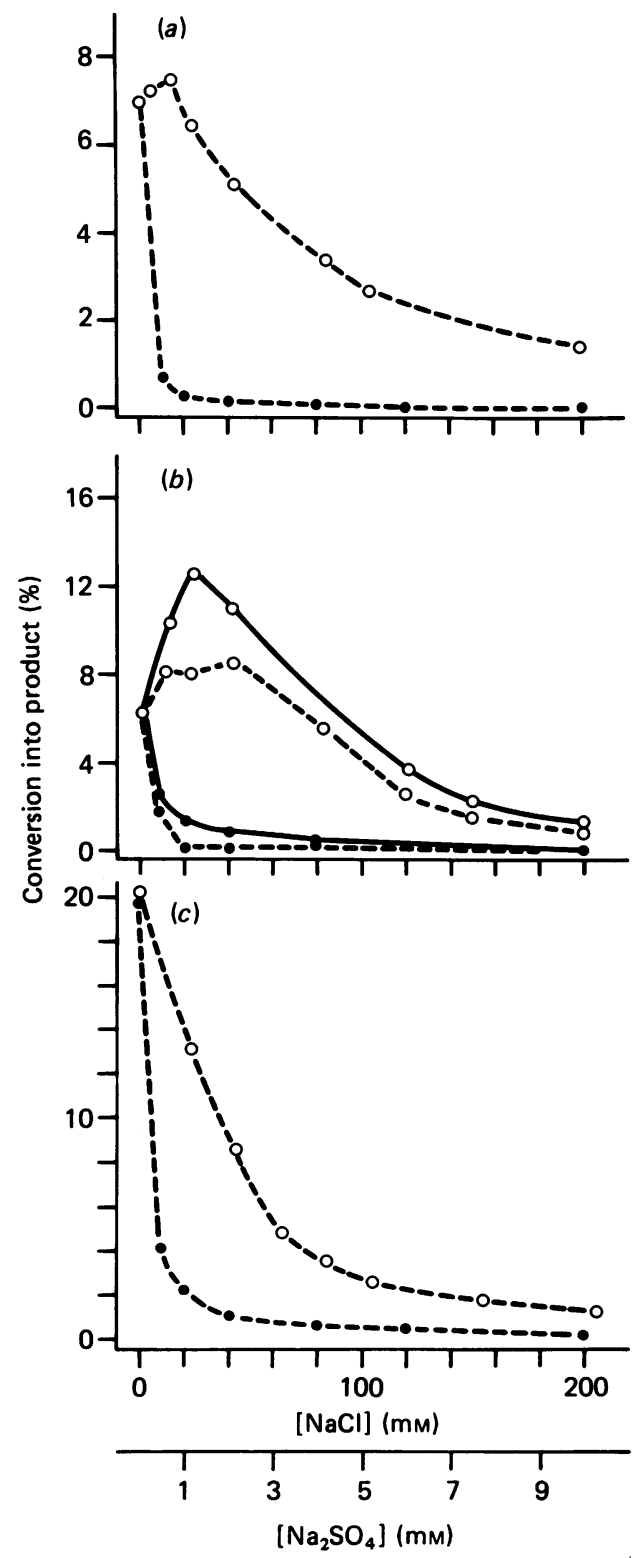

Fig. 3. Hydrolysis by liver sulphamate sulphohydrolase of a variety of substrates as a function of $\mathrm{NaCl}(O)$ and $\mathrm{Na}_{2} \mathrm{SO}_{4}(\mathrm{O})$ concentration at pH $5.6(---)$ and 3.6 $(\longrightarrow)$

(a) GlcNS-IdoA; (b) GlcNS-IdoA2S-anM6S; (c) GlcNSIdoA-GlcNS-IdoA.

\section{DISCUSSION}

We have purified sulphamate sulphohydrolase from human liver to homogeneity by a rapid three-step procedure that includes a concanavalin A-Sepharose/ Blue A Matrex agarose recycling step and separate chromatography steps with hydroxyapatite and CMSepharose. On the basis of yield of enzyme activity, recoveries of up to $20 \%$ and purifications of at least 20000 -fold to a single major band of silver-stained material on SDS/polyacrylamide-gel electrophoresis were obtained from the more than 50 times we have used this preparative method. The enzyme consistently had a subunit $M_{\mathrm{r}}$ of 56000 and a native protein $\mathrm{M}_{\mathrm{r}}$ of 100000 
(Fractogel TSK) to 125000 (Sephacryl S-300), which is probably the result of subunit dimerization. In preliminary studies of the effect of ionic strength and buffer $\mathrm{pH}$ on subunit aggregation we were unable to alter the enzyme's native protein $\boldsymbol{M}_{\mathrm{r}}$. This result is different from a finding we have reported for $\alpha$-L-iduronidase, another lysosomal enzyme involved in heparan sulphate degradation, in which buffer $\mathrm{pH}$ and ionic strength influenced subunit aggregation (Clements et al., 1985a). We reported previously that human liver sulphamate sulphohydrolase has a native protein $M_{\mathrm{r}}$ of 190000 and that higher enzymically inactive aggregates were also present (Mahuran et al., 1983a). Using enzyme prepared by the method now described (in the Methods section) we have been unable to reproduce this result, and for six different preparations tested we find native protein $M_{\mathrm{r}}$ values between 120000 and 125000 on Sephacryl S-300. There have been several changes made to the preparative scheme reported previously, which may influence the ability of the enzyme to aggregate. However, we have repeated the procedure of Mahuran et al. (1983a) and find native protein $M_{\mathrm{r}}$ values of 190000 for two separate enzyme preparations. The native protein $M_{\mathrm{r}}$ values of 120000-125000 that we have reported for the liver, placenta and kidney enzymes are similar to the value of 110000 reported by Paschke \& Kresse (1979) for active enzyme isolated from placenta. The existence of only one pI form for the liver enzyme was demonstrated by using two different substrates (GlcNS-IdOA and GlcNSIdoA2S-anM6S) to locate a single peak of enzyme activity with a pI of 6.8 .

A major conclusion from the kinetic data, summarized in Table 1 , is that the aglycone structure of GlcNS substrates considerably influences the catalytic efficiency of sulphamate sulphohydrolase. An extreme example of this is the most complex of the chemically derived substrates, GlcNS-IdoA2S-anM6S, which is turned over by the purified human liver enzyme more than 300000 -fold faster than is the monosaccharide GlcNS. There appear to be many GlcNS aglycone structural aspects that contribute to the susceptibility of substrates to hydrolysis by sulphamate sulphohydrolase. In the discussion that follows we attempt to define the nature and to quantify the influence of various components of substrate structure on enzyme activity.

It would appear that the relatively fixed structures of the physiological substrates in vivo (heparin and heparan sulphate) are introduced through the substrate structure requirements of the enzymes involved in substrate biosynthesis and are used to advantage (high turnover rates) by enzymes in the degradative pathway. For example, because the presence of GlcNS residues in precursor heparin chains favours the 5-epimerization of GlcA residues, the $\mathrm{C}-2$ sulphation of IdoA residues and the C-6 sulphation of GlcNS residues are likely to result in many of the GlcNS residues in heparan sulphate having a IdoA2S-GlcNS6S aglycone structure (Jacobsson \& Lindahl, 1980; Jacobsson et al., 1984). A finding also consistent with observations that modification by maturation enzymes (i.e. those involved in 5-epimerization and $O$-sulphation) will occur preferentially or exclusively in the.vicinity of GlcNS residues is that heparan sulphate has been shown to contain blocks of $N$-sulphated disaccharides (GlcNS6S-IdoA2S) interspersed with blocks of $\mathrm{N}$-acetylated disaccharides (GlcNAc-GlcA) (Fransson et al., 1980; Rodén, 1980). Of all of the aglycone structures evaluated in Table 1 , substrates containing features such as adjacent-residues C-6 carboxy and C-2 sulphate ester groups and/or a second GlcNS residue were most susceptible to hydrolysis by sulphamate sulphohydrolase.

The addition of a C- 6 carboxy group to a substrate (e.g. compare GlcNS-Ido and GlcNS-IdOA; Table 1) resulted in the largest (more than 200-fold) increase in enzyme turnover number for a single change in aglycone structure. As all known physiological substrates for sulphamate sulphohydrolase in vivo have adjacent-residue C-6 carboxy groups, it is likely that this structural feature plays an important role in the mechanism of hydrolysis of non-reducing-end GlcNS sulphamate bonds. The C-6 carboxy group, however, would appear not to be important in substrate binding, as the $K_{\mathrm{m}}$ value is increased 5-fold with a disaccharide substrate containing a C-6 carboxy group (GlcNS-IdOA) compared with a disaccharide substrate without the adjacent-residue C-6 carboxy group (GlcNS-Ido). One contribution of the C-6 carboxy group to the mechanism of catalysis may be via charge interaction of substrate and enzyme to stretch the sulphamate bond to be broken. A model where the GlcNS residue binds to the enzyme leaving the charged groups of the enzyme, which interact with the substrate carboxy group, just beyond reach so that stretching of the sulphamate bond to be broken, results when the substrate binds through the carboxy group. This may, in part, provide extra energy to overcome the activation energy barrier, thus allowing hydrolysis to proceed at the increased rate observed. We have proposed a similar involvement for the carboxy group of $\alpha$-L-iduronides during hydrolysis of heparan sulphate and dermatan sulphate by $\alpha$-L-iduronidase (Clements et al., 1985b). Ionic interaction of substrate carboxy groups with basic residues present in the enzyme is one possible explanation consistent with the observed effect of substrate structure and of reaction-mixture ionic strength and $\mathrm{pH}$ on kinetic parameters. Arginine residues have been implicated as components of substrate-binding sites for other enzymes acting on anionic substrates or cofactors (Riordan et al., 1977; Gacesa et al., 1981); however, other basic residues may also be involved (Rome et al., 1978).

Interaction of the GlcNS residue and enzyme is apparently via the $\mathrm{C}-4$ hydroxy and sulphamate groups, since the $K_{\mathrm{m}}$ value for GlcNS is 23-fold lower than that for GalNS. A strong involvement of the C-4 hydroxy group may be one of the control features preventing the hydrolysis of internal and therefore C-4-substituted GlcNS residues in, for example, the tetrasaccharide substrate GlcNS-IdoA-GlcNS-IdOA. The combined contribution of the C-4 hydroxy group in the GlcNS residue and the C-6 carboxy group in the adjacent IdoA residue to overall interaction with the enzyme must be considerable, since GlcN-IdOA was shown to inhibit hydrolysis of GlcNS-IdOA under conditions where the monosaccharides GlcN and GlcA have no detectable effect.

Other aglycone structural features of substrates that appear to influence catalytic efficiency and/or binding affinity include a C-2 sulphate ester on IdoA or Ido and an additional GlcNS-IdOA disaccharide residue to produce the tetrasaccharide GlcNS-IdoA-GlcNS-IdOA. The addition of GlcNS-IdOA disaccharide resulted in a large increase in catalytic efficiency without a significant change in pH-activity profile. It is not known whether 
this result reflects a requirement for an intact adjacent uronic acid residue, a post-penultimate GlcNS residue or a second carboxy group three residues removed from the $N$-sulphate bond under enzymic attack. The most catalytically efficient substrate is the trisaccharide containing an adjacent IdoA2S residue.

The influence of substrate aglycone structure on $\mathrm{pH}$ optima of the enzyme activity is considerable. The results observed for sulphamate sulphohydrolase suggest the involvement of a series of ionizable groups in the binding and/or catalysis with $\mathrm{p} K_{\mathrm{a}}$ values corresponding to the various $\mathrm{pH}$ maxima observed for each substrate. For example, as shown in Figs. $2(a)-(f)$, the binding of GlcNS, IdoA, IdoA2S and GlcNS6S substrate residues may involve ionizable groups on the enzyme with approximate $\mathrm{p} K_{\mathrm{a}}$ values of $6.7,5.6,4.2$ and 3.8 respectively. This simplified concept may be more complex if, for example, the binding of substrate to enzyme perturbs the $\mathrm{p} K_{\mathrm{a}}$ of the active site. However, the presence of at least two distinct peaks of activity for some of the more-complex substrates, such as GlcNS6S-IdOA and GlcNS-IdoA2S-anM6S, is consistent with the involvement of at least two ionizable groups in the process(es) of catalysis and/or binding. The addition of $\mathrm{NaCl}$ to abolish the maxima and depress activity is consistent with the suggestion that groups involved in $\mathrm{pH}$-dependent catalysis undergo ionic interaction.

The presence of C-6 sulphate esters on the GlcNS residue under enzymic attack has a marked effect on enzyme activity. It appears that if the C-6 sulphate ester is present on a substrate also containing a C-6 carboxy group on the adjacent monosaccharide residue (compare GlcNS6S-IdOA and GlcNS-IdOA) there is at least a 100 -fold decrease in turnover number for GlcNS hydrolysis. The affinity of enzyme for substrate is increased 15-fold and there is a considerable change in the manner in which $\mathrm{pH}$ influences enzyme activity. One interpretation of these results is that the presence of C-6 sulphate ester on the non-reducing-end GIcNS residues results in both stronger binding of substrate and enzyme and diminished hydrolysis of the sulphamate bond. This may have the effect of channelling these substrates to be first hydrolysed by a GlcNS6S sulphatase to yield a substrate (GlcNS) that is more efficiently hydrolysed by sulphamate sulphohydrolase. We have previously shown that GlcN6S-Ido2S is a very poor substrate in vitro for GlcNS6S sulphatase (Hopwood \& Elliott, 1981c), suggesting that if sulphamate sulphohydrolase acts on GlcNS6S substrates the product (GlcN6S), a potential substrate for GlcNS6S sulphatase, may form a dead-end complex with the enzyme and therefore not proceed further along the degradative pathway. In the absence of an adjacent-residue C-6 carboxy group, C-6 sulphation of a GlcNS residue under attack by the sulphamate sulphohydrolase produces substrates that have higher affinities and catalytic efficiencies than those substrates with C-6-sulphate-free GlcNS groups. This is an artificial situation, as there are no known natural substrates without an adjacent monosaccharide C-6 carboxy group, further highlighting the importance of using substrates that match the structure of the natural substrates to study the enzymology of both normal and mutant enzyme preparations.

Finally, we have suggested that some or all of the eight enzymes involved in the degradation of the complex structured substrateheparan sulphate could by association with each other form an enzyme cluster (Clements $e t$ al., 1985a). This type of association would be expected to improve considerably the overall catalytic efficiency of the system by facilitated diffusion of the product of one enzyme that becomes the substrate for the next enzyme (Wombacher, 1983). The observed high catalytic specificity for substrate structure and the inhibition of sulphamate sulphohydrolase by substrates (e.g. IdoAanM6S, IdoA2S-anM6S, GlcN-IdOA and GlcNAc6SIdOA) of other enzymes involved in heparan sulphate degradation support this cluster-formation hypothesis. It is possible that sulphamate sulphohydrolase could be associated with acetyl-CoA:glucosamine $N$-acetyltransferase (the next enzyme in the heparan sulphate degradative 'pathway'), which has been shown to be an integral protein of the lysosomal membrane (Pohlmann et al., 1981; Hopwood et al., 1983; Freeman et al., 1983).

The work was supported by grants from the Research Trust of the Adelaide Children's Hospital and the National Health and Medical Research Council of Australia. We thank Ms. Helen Elliott for help with substrate synthesis, Dr. P. Clements (Department of Chemical Pathology, Adelaide Children's Hospital) for helpful discussions and Dr. A. Bourne (Department of Histopathology, Adelaide Children's Hospital) for supplying some of the autopsy material.

\section{REFERENCES}

Andrews, P. (1970) Methods Biochem. Anal. 18, 1-53

Clements, P. R., Mahuran, D. J. \& Hopwood, J. J. (1983) J. Chromatogr. 261, 77-82

Clements, P. R., Brooks, D., Saccone, G. \& Hopwood, J. J. (1985a) Eur. J. Biochem. 152, 21-28

Clements, P. R., Muller, V. J. \& Hopwood, J. J. (1985b) Eur. J. Biochem. 152, 29-34

Fransson, L.-A., Sjöberg, I. \& Havsmark, B. (1980) Eur. J. Biochem. 106, 59-69

Freeman, C., Clements, P. R. \& Hopwood, J. J. (1983) Biochem. Int. 6, 663-671

Gacesa, P., Savitsky, M. J., Dodgson, K. S. \& Olavesen, A. H. (1981) Biochim. Biophys. Acta 661, 205-212

Hopwood, J. J. (1979) Carbohydr. Res. 69, 203-216

Hopwood, J. J. \& Elliott, H. (1981a) Clin. Chim. Acta 112, $55-66$

Hopwood, J. J. \& Elliott, H. (1981b) Clin. Sci. 61, 729-735

Hopwood, J. J. \& Elliott, H. (1981c) Carbohydr. Res. 91, 165-190

Hopwood, J. J. \& Elliott, H. (1982) Clin. Chim. Acta 123, 241-250

Hopwood, J. J., Freeman, C., Clements, P. R., Stein, R. \& Miller, A. L. (1983) Biochem. Int. 6, 823-830

Jacobsson, I. \& Lindahl, U. (1980) J. Biol. Chem. 255, 5094-5100

Jacobsson, I., Lindahl, U., Jensen, J. W., Rodén, L., Prihar, H. \& Feingold, D. S. (1984) J. Biol. Chem. 259, 1056-1063

Kresse, H. (1973) Biochem. Biophys. Res. Commun. 54, 1111-1118

Mahuran, D., Clements, P. \& Hopwood, J. (1983a) Biochim. Biophys. Acta 757, 359-365

Mahuran, D., Clements, P. R., Carella, M. \& Strasberg, P. M. (1983b) Anal. Biochem. 129, 513-516

Markwell, M. K., Haas, S. M., Bilber, L. L. \& Tolbert, N. E. (1978) Anal. Biochem. 87, 211-222

Matalon, R. \& Dorfman, A. (1974) J. Clin. Invest. 54, 907-912

McKusick, V. \& Neufeld, E. (1983) in The Metabolic Basis of Inherited Disease (Stanbury, J. B., Wyngaarden, J. B., Fredrickson, D. S., Goldstein, J. L. \& Brown, M. S., eds.), 5th edn., pp. 751-771, McGraw-Hill, New York

Merril, C. R., Goldman, D., Sedman, S. A. \& Ebert, M. H. (1981) Science 211, 1437-1438 
Paschke, E. \& Kresse, H. (1979) Biochem. J. 181, 677- 684

Pohlmann, R., Klein, U., Fromme, H. G. \& von Figura, K. (1981) Hoppe-Seyler's Z. Physiol. Chem. 362, 11991207

Riordan, J. F., McElvany, K. D. \& Borders, C. L., Jr. (1977) Science 195, 884-886

Received 10 June 1985/27 August 1985; accepted 14 October 1985
Rodén, L. (1980) in The Biochemistry of Glycoproteins and Proteoglycans (Lennarz, W. J., ed.), pp. 267-371, Plenum Press, New York

Rome, L. H., Garvin, A. J. \& Neufeld, E. F. (1978) Arch. Biochem. Biophys. 189, 344-353

Wombacher, H. (1983) Mol. Cell. Biochem. 56, 155-164 